\title{
Research Paper: Intervention and Measures Taken on Comprehensive Health of the People Living in Yazd Eskan Neighborhood
}

\author{
Mohammad Hasan Lotfi ${ }^{1}$ (D) Hosein Malekafzali $^{2}$, Salimeh Zare Abdollahi ${ }^{3}$, Parisa Shojaei ${ }^{4^{*}}$ (D) \\ 1. Department of Biostatistics and Epidemiology, Faculty of Health, Shahid Sadoughi University of Medical Science, Yazd, Iran \\ 2. Department of Biostatistics and Epidemiology, School of Public Health, Tehran University of Medical Sciences, Tehran, Iran. \\ 3. Social Determinants of Health Research Center, School of Public Health, Shahid Sadoughi University of Medical Science, Yazd, Iran. \\ 4. Department of Community and Preventive Medicine, School of Medicine, Tehran Medical Science Branch, Islamic Azad University, Tehran, Iran.
}

\begin{tabular}{|c|c|}
\hline $\begin{array}{l}\text { Use your device to scan } \\
\text { and read the article online }\end{array}$ & Crtation Lotfi MH, Malekafzali H, Zare Abdollahi S, Shojaei P. Intervention and Measures Taken for a Comprehensive \\
\hline 口ifing & $\begin{array}{l}\text { Health of the People Living in Yazd Eskan Neighborhood. Journal of Research \& Health. 2021; 11(5):313-322. http://dx.doi. } \\
\text { org/10.32598/JRH.11.5.1892.1 }\end{array}$ \\
\hline 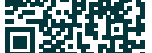 & del http://dx.doi.org/10.32598/JRH.11.5.1892.1 \\
\hline
\end{tabular}

\section{$(1)(3)$}

Article info:

Received: 12 Apr 2021

Accepted: 07 Jul 2021

Publish: 01 Oct 2021

\section{Keywords:}

Participation, Development, Neighborhood, Health, Intervention, Action

\section{A BSTRACT}

Background: The community participation concept has different implications for various individuals.

Methods: This research was Community-Based Participatory Research (CBPR), which was done in Yazd. The settlement area with a population of 16,000 people is located on the western outskirts of Yazd. With the implementation of health transformation programs in the 11th government, first, the health base in 2016 and then, Dr. Malekafzali Comprehensive Health Services Center in this area have been set up and started to work in 2016 to provide various health services to the residents of this area. Considering the potentials of this neighborhood, including high social cohesion and the existence of a dynamic and popular non-governmental organization, since 2017, this place has been a candidate for the implementation of empowerment and optimal development of neighborhood health (Tabassom project). The steps of implementing the optimal Health development plan (Tabasaom) involved five steps of the area identification, organizing, empowerment, requirement assessment, and intervention and action. The stage of intervention and action was covered in this article.

Results: Most of the problems that appeared in this study were non-health issues, encompassing a wide range of issues in other social, cultural, and economic fields.

Conclusion: Identified issues consisted of a wide variety of problems that were needed to be resolved through interdisciplinary activities, the support of managers and officials, and the active participation of the community.

\footnotetext{
* Corresponding Author:

Parisa Shojaei, PhD.

Address: Department of Community and Preventive Medicine, School of Medicine, Tehran Medical Science Branch, Islamic Azad University, Tehran, Iran. Phone: +98 (919) 2965126

E-mail:shojaee7@gmail.com
} 


\section{Introduction}

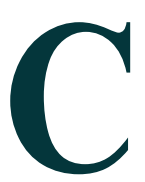

ommunity participation was attributed to the interaction of individuals and communities in making decisions on factors that affected their lives [1]. It was obvious that there were quite different perspectives on the participation of the community, how it was formed, and whether it should be from top-down or bottom-up [2]. In the literature on participation, it was recognized that community participation, due to its nature, needed issues connected to power and control [3]. Usually, the term participation is modified with adjectives, resulting in terms, such as community participation, citizen participation, people's participation, public participation, popular participation, etc. [4]

O'Faircheallaigh pointed out that participation is the dissemination of information, incorporating communities in the decision-making process, considering the view of the community, and enabling the community concerning the power to influence the decision process [5]. The issue of neighborhood participation lied in the planning between two sets of conflicts: between public and personal interests, and between more hard and soft governance [6]. The concept of community capacity is the ability of a group to identify and act on problems that have become very significant in the field of health promotion [7]. Concerning features, such as participatory, process planning approach, increasing people's control over livelihood and daily life, and offering plans and programs that were more dependent on needs and local situation of communities, this new planning could be a desirable pattern for planning and democracy [8]. The lack of opportunity for citizen involvement in decisionmaking is a significant theme in the contemporary critique of public services [9].

Community development has built its literature, which has benefited from the efforts of scholars from several disciplines [10]. The practice of community development has been codified into common phrases, strategies, and tasks [11]. Eskan region with a population of 16,000 is located on the western outskirts of Yazd. After implementing the health system reform plan in the 11th government, the comprehensive health services center of this region began operating in 2016 to provide various health services to the residents of this region. Due to the potential of this region, including Non-Governmental Organizations (NGOs), this region was a candidate in implementing the empowerment and optimal development of neighborhood health. The purpose of optimal development of neighborhood health was community organiza- tion, empowering the people of the neighborhood, and supporting the people in terms of using their capabilities and potentials in identifying and solving neighborhood problems, encouraging self-reliance in community members to control the health of themselves and their families, as well as controlling the health of their living environment, and participation in identifying and eradicating problems and being empowered for having a better environment. The aim of this plan was to propose a pattern for organizing and empowering the community to recognize the needs and prioritize them for the development of the Eskan neighborhood of Yazd province.

\section{Methods}

The methodology of the study was Community-Based Participatory Research (CBPR) conducted to develop the Eskan neighborhood in Yazd from 2017 to 2019. First, we explained all the officials and people involved in individual and group meetings, and these meetings were for influential people and even people outside the neighborhood, including the municipality, the governorate, and those who could be influential, positive, or supportive, or even for security issues. Therefore, the first step was to hold briefings. It was necessary to justify all organizations, institutions, socio-security officials, and more importantly, the people themselves, NGO donors, the private sector, and all those who could somehow play a role in advancing or stopping this project. This procedure was done using letters, posters, conferences, and meetings. This stage took three months.

Similar studies have been conducted with the participation of people and neighborhood officials in the Azerbaijan neighborhood of Tehran [12], Chahestani neighborhood of Bandar Abbas [13], Mehdi Abad and the Bastam city in the of Shahroud city [14], Gonabad [15], Alani village of the Meshkinshahr functions, a rural area in Nigeria [16], the US state of Tulsa [17], and one of the neighborhoods of Buenos Aires, Argentina [18] and have shown that although there were problems in these communities in general in more or fewer areas, the main issue is similar (social, development, management, security, housing, health, economic issues, etc.), the variety of problems in each field is different in these societies, which has a root in differences in social variables. Different economic and cultural communities are a clear reason for the need's assessment and identification of the problems of each society by its people. Also, a significant number of problems raised by the people were in the civil and social fields. 
The implementation stages of the optimal plan for the development of neighborhood health (Tabassom) involved 5 steps of 1) Area identification, 2) organization, 3) empowerment, 4) Requirement assessment and prioritization, and 5) intervention and action and 14 steps, including:

Step 1: Justifying the stakeholders

Step 2: Census

Step 3: Clustering

Step 4: Selecting a cluster-head

Step 5: Forming a health center

Step 6: Empowerment

Step 7: Determining ten priorities in each cluster

Step 8: Forming a neighborhood health assembly

Step 9: Selecting 10 final priorities for a neighborhood by aggregation of cluster priorities

Step 10: Preparing working groups

Step 11: Arranging a treaty

Step 12: Implementation

Step 13: Evaluation

Step 14: Documentation and project development

The present study dealt with the intervention and action stage from the eighth to the fourteenth steps.

Requirement assessment and prioritization were their first training, acquaintance, and learning in qualitative research. To this end, university professors were invited to explain qualitative research and hold group discussion meetings with people in simple language to assess the needs and prioritize problems. Therefore, the cluster head had a list of ten priorities in each cluster regarding the conducted qualitative researches. In the formation of the neighborhood health assembly, the association's members, who were about 95 members, added several other groups, including NGOs, universities, and government agencies, and formed the neighborhood health assembly. In step 9 of the selection of 10 final priorities for a neighborhood by aggregation of cluster priorities, the neighborhood health assembly determined in the cluster where the top 10 priorities were discussed in the neighborhood (the criterion was the whole neighborhood, not the cluster). This needs assessment was considered comprehensively, and only the patients were not focused, which was known as a social approach. Then, in the step of forming working groups, each of 10 priorities was formed, and the organizations were created to solve the priority problems and gather the interested people. Here, the aim was specifying the manner of intervening in problem-solving. Thus, this working group was worth considering and identified the resources available in the neighborhood and the facilities of the organizations, the help of benefactor people and the private and government sector, universities, and the other factors by holding various meetings.

Utilizing these working groups, all the facilities and potentials were collected, and fundamental decisions and appropriate solutions were made and adopted to obviate the problems. First, the reasons for the existence of the problem of brainstorming were proposed, and then, the solutions were investigated. The solutions were characterized by the following features: 1 . they were tailored to the intrinsic functions of the body, 2. they were tailored to the capabilities and potentials of the region, the authorities, and the people, 3 . the strategies were changeable, 4 . the duration of change was also partially obvious (short-term, medium-term, long-term). Therefore, a treaty was arranged after specifying the solution/final solutions and determining the manner of participation of the people and authorities.

\section{Step 11: Treaty arrangement}

After determining the working groups and their members, basic decisions and strategies must be written down. In this regard, contracts or treaties were arranged, in which the duties and obligations of the people, universities, and government agencies were settled exactly like a real treaty. The Gantt charts in the treaties specified each task, which would be taken place in the neighborhood through asking by whom, when, by which quality and criteria. These charts (like documents) specified the duty of each person. We did not find the oral Gantt charts in the treaty sufficient, and both signs and duties were assigned for people and the organizations. The structure of the treaty was as follows:

a. Statement of the problem

b. Statement of the reasons for the problem

c. Statement of problem-solving strategies 
d. Statement of commitments and partnership

- cluster head and the people of the neighborhood

- Related inter-departmental offices

- Health team of Dr. Malekafzali Center

e. Duration of the treaty

f. Gantt charts and evaluation indicators

g. The sign of stakeholders and committed people

\section{Step 12: Implementation}

The next step was implementation according to the Gantt chart, and the cluster head was required to monitor the implementation of the activities and ask for help for a progress report and tackling the obstacles in the assembly while holding the assembly meetings.

The treaties were then signed by the relevant working group (chairman of the board, board liaison in the working groups, and the official with the highest degree in charge of the relevant departments in the region).

Moreover, the Gantt table was assigned for the implementation of the solutions mentioned in the treaty, in which the title of the activity, the person in charge of the implementation, the duration of the implementation, and the evaluation indicator, etc. were appointed. The Gantt chart, as an action plan, was annexed to the treaty after agreement and approval. After the completion of the treaties, the optimal plan for the development of neighborhood health (Tabassom) entered the intervention phase, and each organ, body, and organization performed its commitments. The board liaison of the difficult working group and a health team liaison was in charge of following up the commitments, coordinating, and cooperating with the departments. However, the board liaison in the working group created cyberspace. All members of the working group and the officials were responsible for implementing the activities (as stipulated in the Gantt chart), and cluster head-. In this cyberspace group, actions, information, work processes (flowcharts, algorithms, etc.) public requests, and progress of work were explained. Also, people and cluster head could raise their problem-solving and suggestions in their neighborhoods. However, in the monthly meetings, the members of the working group were able to report the progress of the activities and problem-solving, and then, represent the administrative problems and expectations and suggestions in person in the sessional meetings in the conference of the neighborhood health assembly.

The next step was the evaluation and monitoring stage. The cluster head was responsible for monitoring while performing the work. In cooperating with the members of the assembly, the cluster head compiled the monitoring indicator to check whether the problem was solved while fulfilling the work with the desired indicator and whether people were satisfied. Academics had the main role in facilitating in this regard.

\section{Results}

As specified in the needs assessment and prioritization phase, the first priority was attributed to waste-related problems (Table 1).

\section{First priority: Waste management working group}

1. Receiving and distributing 170 Plast cartoons to schools and gathering centers (cluster head and people, Waste Organization, and Municipality)

2. Establishing dry waste station in front of the Comprehensive Health Center of Dr. Malekafzali (cluster head and people, Waste Organization, and Municipality)

3. Delivering 20 information banners about collecting "wet waste" by the municipality (cluster head and people and Municipality)

4. Informing the cluster head in the neighborhood with the aim of using Conex for storing dry waste and the time for collecting wet waste (cluster head and people, and Municipality)

5. Teaching school-aged children, preschoolers, and people about waste management by health team (cluster head and people and Municipality)

6. Donation of 500 flower vases for delivering dry waste to the fixed station of dry waste (cluster head and people and Municipality)

7. Holding a competition for recycling partners (cluster head and people, Waste Organization, and Municipality)

8. Using specialized trainers in informing and educating in person and announcing programs, collection hours, the manner of separating waste to neighborhood residents (health team, District 1 Education Department, Waste Organization, cluster head and people, and $\mathrm{Mu}-$ nicipality) 
Table 1. Working groups held in the action phase and intervention of the priority problems in the region

\begin{tabular}{|c|c|c|c|c|}
\hline No. & $\begin{array}{l}\text { Working Groups } \\
\text { Name }\end{array}$ & Collaborative Organization & $\begin{array}{l}\text { Number of } \\
\text { Working Group } \\
\text { Meetings }\end{array}$ & $\begin{array}{l}\text { Progress } \\
\text { Percentage }\end{array}$ \\
\hline 1 & $\begin{array}{l}\text { Waste Manage- } \\
\text { ment }\end{array}$ & $\begin{array}{l}\text { University of Medical Sciences/ District } 4 \text { Municipality / Waste } \\
\text { Department of Yazd City / Provincial Environmental Organiza- } \\
\text { tion / District } 1 \text { Education Department / Welfare Department } \\
\text { of Yazd country }\end{array}$ & 20 & 100 \\
\hline 2 & $\begin{array}{l}\text { Asphalt demolition } \\
\text { and lack of asphalt }\end{array}$ & University of Medical Sciences/ District 4 Municipality & 12 & 100 \\
\hline 3 & Lack of park & $\begin{array}{l}\text { University of Medical Sciences / District } 4 \text { Municipality / Hous- } \\
\text { ing and Urban Development Organization of Yazd Province / } \\
\text { Agriculture Jihad Organization of Yazd Province / Natural Re- } \\
\text { sources Organization / Green Space Organization }\end{array}$ & 12 & 90 \\
\hline 4 & $\begin{array}{l}\text { Lack of educational } \\
\text { space }\end{array}$ & $\begin{array}{l}\text { University of Medical Sciences / District } 4 \text { Municipality / Dis- } \\
\text { trict } 1 \text { Education Department / Sports and Youth Organization } \\
\text { of Yazd Province / National Library of Yazd Province / Welfare } \\
\text { department of Yazd City / Housing and Urban Development } \\
\text { Organization / Islamic Propaganda Organization / Technical } \\
\text { and Vocational Training Organization / Academic Center for } \\
\text { Education, Culture and Research (ACECR) / Culture and Islamic } \\
\text { guidance Organization }\end{array}$ & 9 & 80 \\
\hline 5 & Lack of green Space & $\begin{array}{l}\text { District } 4 \text { Municipality / Agriculture Jihad Organization of Yazd } \\
\text { province / Natural Resources Organization of Yazd province / } \\
\text { Parks and Green Space Organization / Cultural, Social, Sports } \\
\text { Organization of the Municipality }\end{array}$ & 12 & 80 \\
\hline 6 & $\begin{array}{l}\text { Lack of secondary } \\
\text { school and high } \\
\text { school }\end{array}$ & $\begin{array}{l}\text { University of Medical Sciences / District } 4 \text { Municipality / Dis- } \\
\text { trict } 1 \text { Education Departments / School Renovation Organiza- } \\
\text { tion / Housing and Urban Development Organization }\end{array}$ & 9 & 80 \\
\hline 7 & $\begin{array}{c}\text { Lack of deed of the } \\
\text { house }\end{array}$ & $\begin{array}{l}\text { University of Medical Sciences / District } 4 \text { Municipality / Jus- } \\
\text { tice Organization of Yazd Province / Housing and Urban Devel- } \\
\text { opment Organization of Yazd Province / Deeds and Real Estate } \\
\text { Organization of Yazd Province }\end{array}$ & 9 & 80 \\
\hline 8 & $\begin{array}{l}\text { Lack of single-line } \\
\text { station, canopy, } \\
\text { and chair }\end{array}$ & $\begin{array}{l}\text { University of Medical Sciences / District } 4 \text { Municipality / } \\
\text { Freight and Passenger Transportation Organization of Yazd } \\
\text { Province }\end{array}$ & 18 & 95 \\
\hline 9 & $\begin{array}{l}\text { Lack of a bank } \\
\text { counter }\end{array}$ & $\begin{array}{l}\text { University of Medical Sciences / Housing and Urban Develop- } \\
\text { ment Organization of Yazd Province / Agent Bank (one of the } \\
\text { banks of Mellat, Refah, Saderat, Tejarat, Melli, etc.) }\end{array}$ & 8 & 80 \\
\hline 10 & $\begin{array}{l}\text { Open and ruined } \\
\text { lands }\end{array}$ & $\begin{array}{l}\text { University of Medical Sciences / District } 4 \text { Municipality / Hous- } \\
\text { ing and Urban Development Organization / Provincial Environ- } \\
\text { mental Organization / Industry, Mining and Trade Organization }\end{array}$ & 12 & 90 \\
\hline
\end{tabular}

9. Delivering the wet waste collection calendar and installing the labels on the doors of houses (cluster head and people and Municipality)

10. Collecting, sweeping, and cleaning the Eskan region according to the conclusion of the treaty with the competent company and using mechanized machinery based on the provisions of the treaty, mechanized collecting waste municipal service fleet, daily and continuous cleaning by street sweeper (cluster head and people and Municipality)
11. Implementing the cleaning engineers project by the neighborhood health center in schools with the cooperation of schools and the district education department

Second priority: Asphalt working group and passage improvement

1. Asphalting all alleys and streets over $14 \mathrm{~m}$ by District 4 Municipality (Municipality)

- Implementing the asphalt completion operations of Shahidan Barotkobzadeh Blvd. with an area of 17000 $\mathrm{m} 2$ with a total credit of 2 billion and 5 hundred million 
Rials by the Municipality (cluster head and people and municipality)

- Infrastructure, asphalt, and civil operations of 40, 56, and 66 Eskan alleys and 2 20-meter passages between 63 and 67 Azadegan alleys with a total area of 20,000 m2 with a total credit of 6 billion Rials (Municipality)

2. Asphalting all alleys less than $14 \mathrm{~m}$ where the presidents paid their share of self-help (cluster head and people and municipality)

3. Asphalting all Eskan passages where residents paid their share of self-help, such as 10 and 18 Eskan alleys, Armaghan alley, Shahid Kahdouie alley with an area of $30,000 \mathrm{~m} 2$ at the cost of 15 billion Rials (cluster head and people and municipality)

4. The stone pavement of the sidewalks of Eskan neighborhood (cluster head and people and municipality)

- Implementing construction operations, installing the curbstone on the main street of Eskan with $2 \mathrm{~km}$ long (Municipality)

- Implementing sidewalk construction operations in Sanat square with an area of $4000 \mathrm{~m} 2$ and part of Eskan Street and sidewalk construction operations along the route (the cost of this project was 3 billion Rials) (cluster head and people and Municipality)

5. Starting the executive operations and constructing underpass bridges on the train route (Arman and 63 Azadegan) (Municipality)

6. Removing soil and debris around the health center for constructing sidewalks and landscaping (health team, cluster head and people, and Municipality)

7. Completing the landscape and walling of the comprehensive health center of Dr. Malekafzali (health team, cluster head, people, and University of Medical Sciences)

8. Constructing bicycle route between Darolebadeh square and 76 Azadegan alley with 500 meters long, and continuing the operation of the route in the current year (health team, cluster head, people, and Municipality)

9. Collection of soil and debris in the alleys connecting the Eskan to Azadegan Blvd. by the contracting company continuously and under the supervision of the deputy of municipal services of this region (cluster head and people and Municipality)

\section{Third priority: Park working group}

1. Starting the construction of two parks in 53 and 58 Azadegan alleys with an area of $8,000 \mathrm{~m} 2$ and a cost of 5 billion Rials (health team, cluster head and people, Municipality, and Parks and Green Space Organization)

Fourth priority: Working group for the lack of educational and cultural space

Forming various working group meetings and brainstorming due to a lack of proper land for using public services. So far, the problem was not completely solved, and there were only a few governments lands that were investigated in order to change them and their application.

Fifth priority: Greenspace working group and beautification

1. Planting operations of trees and green space on Barotkobzadeh Blvd. of the neighborhood (health team, cluster head, people, Municipality, and Parks and Green Space Organization)

2. Donating 100 free olive seedlings to Eskan neighborhood (health team cluster head and people, Municipality, and Agriculture Jihad)

3. Implementing the cleaning operations of the passages, digging absorption wells, implementing speed bumps, and installing prefabricated walls for fencing lands with the unknown owner (with a credit of 1 billion and 500 hundred million Rials) (health team, cluster head and people, Municipality, and Parks and Green Space Organization)

Sixth priority: Lack of working group for the secondary school and high school

Conducting various working group meetings and brainstorming due to the lack of proper land for using public services (lack of land in the area of $2500 \mathrm{~m}$ ) and the existence of only a few governmental lands that were investigated to change their use. In this regard, there were two governmental lands in the area of $1000 \mathrm{~m}$, which were not approved for constructing schools. After different consultations with the officials, a land with an area of $3000 \mathrm{~m} 2$ in out-of-town use was transformed into an urban area and became an educational-cultural complex. This complex is now under construction.

Seventh priority: Lack of working group for deed of the house

Regarding the interdisciplinary legal problems and the existence of waste or unutilized lands in the neighbor- 
hood, which were turned into residential units, the actions were necessarily completed at the national level. The actions were taken to complete the declaration of land status and, in particular, the declaration of the status of government land possession. After completing the relevant forms and sending the land documents to the deeds and properties registration organization of Yazd province, provided that the owner of the property did not have any government land, the area of $100 \mathrm{~m}$ was free, and if the remaining area was more than $100 \mathrm{~m}$, the landowner was obliged to pay a quarter of the ruling price (health team, cluster head, people, and housing organization).

Eighth priority: Bus, single-line station, canopy, and chair working group

1. Laying out and installing the single-line station sign (health team, cluster head and people, Municipality, Municipal Freight and Passenger Transportation Organization, Freight and Passenger Transportation Organization, and Mehr Iran Bank)

2. Constructing the canopy and chairs in front of the comprehensive health center (health team, cluster head-, people, Municipality, and Freight and Passenger Transportation Organization)

3. Determining the route of the buses requested by the community of the neighborhood (health team, cluster head and people, Municipality, Freight and Passenger Transportation Organization)

4. The infrastructure of the canopy and the chair of the single-line station on the airport Blvd. (cluster head and people, Municipality, and Freight and Passenger Transportation Organization)

Ninth priority: Working group for bank branch construction

Concerning the poor economic situation of the people in the region, the banks were less interested in forming and establishing a bank branch in the neighborhood. Only one of the banks had a counter and was providing services. In this regard, with the made efforts and provided that the free location in the neighborhood was handed over, one of the banks announced its readiness to establish a branch and provide services. The necessary action and follow-up were carried out.
Tenth priority: Working group for open and ruined lands

1. Preparing and distributing the algorithm for guidance and action by local people (health team, cluster head and people, Municipality, and Freight and Passenger Transportation Organization)

2. $100 \%$ walling of open lands without ownership by the municipality

\section{Discussion}

Ten first priorities identified in the needs assessment and prioritization phase were waste, asphalt demolition and lack of asphalt, lack of park, lack of educational space, lack of green space, lack of secondary school and high school, lack of deed of the house, lack of singleline station-canopy and chair, lack of bank counters, and open and ruined lands. The first priority and biggest problem of the neighborhood were attributed to waste management. In the population research stations, some interventional projects are currently being implemented along with the defined priorities in the following areas: promoting family health, empowerment, and improving quality of life and environmental health [19].

Solid waste management, therefore, should not be left to the administrators alone, but it should be considered as a community issue. Developing countries are confronted with issues of solid waste management because of its attendant negative impacts on the general wellbeing and environmental safety in urban territories. Hence, solid waste needs to be appropriately managed to get rid of its menace on the general wellbeing and environmental safety [4]. Thomas-Hope postulates that community members are social capital. Therefore, where a community has accumulated strong levels of social capital, it is possible with regard to an environmental issue to reorganize the existing solid waste management system [20]. Thus, Frankham opined that success and viability are much feasible if solutions to community issues are identified and rectified by community development remedies [21].

Community leaders act as key points of contact between governmental regeneration initiatives and local residents in neighborhoods. The effective development of this role, whether conceived of as a social entrepreneur or not, requires the accumulation of two types of social capital: internal communal and external collaborative social capital. Each of these requires gaining mutual trust or goodwill in relation to a wide range of community groups/net- 
works and secondly, regeneration partners drawn from the private and (crucially) the public sectors [9].

Engaging in community participation and effective community representation takes time. Processes are often messy, difficult, and can lead to burnout. Community leaders who remain may be discredited over time as simply "the usual suspects" (see Taylor, earlier in the discussion). For communities and leaders to invest the time and effort for high-quality participation and representation there must be some incentives - that is they must be able to see some results or some evidence that their participation matters.

Fung and Wright (2001) argue that it is mostly possible to gain broad and deep participation in participatory governance approaches, which offer the 'real prospect of exercising state power. With most other forms of political participation, the relationship between, for example, a person's vote or letter to a representative and a public decision is weak at best. In these experiments, however, participants exercise influence over state strategies'. If this is true, one way to strengthen the quality and sustainability of forms of community leadership and participation is to focus on the results and outcomes, which emerge from such engagement [9].

The importance of community participation in any developmental projects has been highlighted, which urban solid waste management cannot be an exception [22-24]. Hence, community participation is key to community success. It is a proven fact that community participation ensures success, once people are engaged in a project as partners it gives them a sense of ownership of the project leading to more sustained attention, effort, and time on task, and enhanced task mastery leads to community success. Moreover, for anything to earn value, it must be given a title of ownership [4]. The new emphasis on participation developed the scope of decision-making and initiated new fields of discussion and legitimacy. The issue was the manner of properly and correctly creating participation in local communities [25]. It was remarkable to perceive that community participation was observed as a dynamic process.

There were several factors or determinant factors that were able to identify the nature of the results of development programs or their health and sustainability. Professional programmers and developers were required to know that the type of social problems in community participation was a dynamic process, in which goals and strategies changed over time [26]. The socio-cultural, political, and economic environment in society probably influenced the extent of participation, and its sustainability could only be achieved when the related actors were committed to that environment [27]. The mechanism or set of complementary mechanisms was obliged to respect the role of societies in identifying issues that needed observation and design effective responses to them, and ultimately, they should recognize that the changes required time. While regional development programs must have a "living document", the executive and administrative arm of the government was also supposed to provide the time needed for implementing programs before the early development of new cases [28].

\section{Conclusion}

The results of this study illustrated that the requirements of the people of each society varied concerning the cultural, social, and economic conditions of that society. Moreover, based on the degree of development of the region or neighborhood, the major infrastructure, and environmental problems were first considered by people due to slum-dwelling and deprivation in the first stage, and the needs assessment and prioritization of issues of this group in the Eskan neighborhood were more proposed. Obviating the mentioned problems led to the social and psychological health improvement of the people. Therefore, for promoting comprehensive health and solving the problems of each neighborhood, it was recommended to start, follow up, and implement the determination of the needs and prioritize them with the participation of the people of the neighborhood to maintain this improvement more stable and sustainable.

\section{Limitation}

The limitations of this study were as follows:

1. Excessive shedding of threads (absorption and retraining) at each stage of work

\section{Unmotivated people and officials}

3. In the early stages of the project, most of the work had to be done by the facilitators and the health team themselves, and most of the euphemisms were supported. The partnership is still taking shape.

4. Turmoil and storming of groups due to neighborhood or group issues (presentation of reports on the work of other heads by the chairman of the board and the invisibility of the activities of other heads, not taking into account some comments of the heads, etc. 
5. Expecting euphoria from material encouragement, such as pilgrimage or liaisons, etc.

$6.60 \%$ of the identified priority problems were related to the municipality

\section{Parallel work with other inter-sectoral organs}

8. Attracting the participation of the people of the neighborhoods is the responsibility of the city councils according to the resolution of the Islamic Consultative Assembly, and the Ministry of Interior is also taking care of its implementation

It is necessary for a mechanism or set of complementary mechanisms to respect the role of communities in identifying issues that need attention and to design effective responses to them.

\section{Ethical Considerations}

\section{Compliance with ethical guidelines}

Ethical approval was provided by the Iran Research Ethics Committee of Shahid Sadoughi University of Medical Sciences, Yazd (Code: IR.SSU.REC.1396.212).

\section{Funding}

This research was supported by the Vice-Chancellor for Health, Shahid Sadoughi University of Medical Sciences, Yazd.

\section{Authors' contributions}

Conceptualization, funding acquisition and resources: Mohammad Hasan Lotfi, Hosein Malekafzali; Methodology: All authors; Investigation, writing - original draft and writing - review \& editing: Salime Zare Abdollahi and Parisa Shojaei; Data collection, data analysis: Mohammad Hasan Lotfi and Salime Zare Abdollahi.

\section{Conflict of interest}

The authors declared no conflict of interest.

\section{Acknowledgments}

The authors are grateful to the residents of the Eskan Neighborhood for their tremendous and sincere cooperation.

\section{References}

[1] Burns D, Heywood F, Taylor M, Wilde P, Wilson M. Making community participation meaningful: A handbook for development and assessment. Bristol: Joseph Rowntree Foundation; 2004. https://books.google.com/ books?id=ZnhFj0UUAH4C\&dq

[2] Rifkin SB, Lewando-Hundt G, Draper A. Participatory approaches in health promotion and health planning: A literature review. London: Health Development Agency; 1999. https://library.wur.nl/WebQuery/titel/1716921

[3] Madon S, Malecela MN, Mashoto K, Donohue R, Mubyazi G, Michael E. The role of community participation for sustainable integrated neglected tropical diseases and water, sanitation and hygiene intervention programs: A pilot project in Tanzania. Soc Sci Med. 2018; 202:28-37. [DOI:10.1016/j. socscimed.2018.02.016. https://pubmed.ncbi.nlm.nih. gov/29501716/] [PMID] [PMCID]

[4] Maiyaki MA, Marzuki A, Mustafa RIA. A review of rationale of community participation in urban solid waste management in Nigeria. Int Trans J Eng Manag Appl Sci Technol. 2018; 9(3):185-96. https:/ / tuengr.com/V09/185M.pdf

[5] O'Faircheallaigh C. Public participation and environmental impact assessment: Purposes, implications, and lessons for public policy making. Environ Impact Assess Rev. 2010; 30(1):19-27. [DOI:10.1016/j.eiar.2009.05.001]

[6] Mace A, Tewdwr-Jones M. Neighborhood planning, participation, and rational choice. J Plann Educ Res. 2017; 39(2):184-93. [DOI:10.1177/0739456X17727334]

[7] Cadiz D, Sawyer JE, Griffith TL. Developing and validating field measurement scales for absorptive capacity and experienced community of practice. Educ Psychol Meas. 2009; 69(6):1035-58. [DOI:10.1177/0013164409344494]

[8] Bandura A. Self-efficacy in changing societies. Cambridge: Cambridge University Press; 2004. [DOI:10.1017/ CBO9780511527692]

[9] Gaventa J. Representation, community leadership and participation: Citizen involvement in neighbourhood renewal and local governance [Internet]. 2004 [Updated Jul 2004] Available from: https://assets.publishing.service.gov.uk/ media/57a08cd8ed915d3cfd001664/JGNRU.pdf

[10] Christenson JA, Robinson JW. Community development in America. Iowa City: Iowa State University Press; 1980 https:// books.google.com/books?id=sTRHAAAAMAAJ\&q

[11] Florin P, Wandersman A. An introduction to citizen participation, voluntary organizations, and community development Insights for empowerment through research. Am J Community Psychol. 1990; 18(1):41-54. [DOI:10.1007/BF00922688]

[12] Zaeri S, Asgharzadeh S, Khoshnevis S, Mohammadi M, Holakouie Naeini K. Identification of community needs and prioritization of problems based on community assessment in Azerbaijan Borough, Tehran, Iran. J Sch Public Health Inst Public Health Res. 2011; 9(2):69-78. https://web.a.ebscohost. com/abstract?direct

[13] Mohammadi Y, Javaheri M, Mounesan L, Rahmani K, Holakouie Naeini K, Madani A, et al. Community assessment for identification of problems in Chahestani Region of BandarAbbas city. J Sch Public Health Inst Public Health Res. 2010; 7(4):21-30. https://web.p.ebscohost.com/abstract?direct 
[14] Madani AH, Shekari M, Nejatizadeh A, Aghamolaei T, Azarpakan A, Holakouei Naeini K. [Community assessment to identify and prioritize problems of Hormoz Island, in the South of Iran (Persian)]. J Prev Med. 2016; 2(4):58-70. http:// jpm.hums.ac.ir/article-1-123-en.html

[15] Delshad A, Salari H, Khajavi A, Shafaghi K, Marouzi P, Mohammadpour A, et al. [Certifying of the society felt needs based on community as partner model in Gonabad population lab. Boundaries (Persian)]. Horizon Med Sci. 2005; 10(4):15-22. https:// www.sid.ir/fa/journal/ViewPaper.aspx?ID=40264

[16] Anyanwu CN. The technique of participatory research in community development. Community Dev J. 1988; 23(1):11-5. [DOI:10.1093/cdj/23.1.11] [PMID]

[17] Johnson CV, Bartgis J, Worley JA, Hellman CM, Burkhart R. Urban Indian voices: A community-based participatory research health and needs assessment. Am Indian Alsk Native Ment Health Res. 2010; 17(1):49-70. [DOI:10.5820/ aian.1701.2010.49] [PMID]

[18] Lotersztain M, Zorat M, Lecouna M, Motta M. Use of the rapid appraisal method for the identification of perceived needs in a low-class barrio in the city of Buenos Aires. Aten Prim. 2000; 26(10):690-2. [DOI:10.1016/S0212-6567(00)78753-1]

[19] Malekafzali H. Community Based Participatory Research: Review of a Model in Islamic Republic of Iran. Deputy for Research and Technology, Ministry of Health and Medical Education, 2005.

[20] Thomas-Hope EM. Solid waste management: Critical issues for developing countries. Barbados: Canoe Press; 1998 https:/ / books.google.com/books?id=QACfDLFXzncC\&dq

[21] Frankham J. Partnership research: A review of approaches and challenges in conducting research in partnership with service users [Internet]. 2009 [Updated 2009]. Available from: https://eprints.ncrm.ac.uk/id/eprint/778/

[22] Ahmed SA, Ali M. Partnerships for solid waste management in developing countries: Linking theories to realities. Habitat Int. 2004; 28(3):467-79. [DOI:10.1016/S01973975(03)00044-4]

[23] Tukahirwa JT, Mol AP, Oosterveer P. Civil society participation in urban sanitation and solid waste management in Uganda. Local Environ. 2010; 15(1):1-14. [DOI:10.1080/13549830903406032]

[24] Rathi S. Alternative approaches for better municipal solid waste management in Mumbai, India. Waste Manag. 2006; 26(10):1192-200. [DOI:10.1016/j.wasman.2005.09.006] [PMID]

[25] Campbell C, Jovchelovitch S. Health, community and development: Towards a social psychology of participation. J Community Appl Soc Psychol. 2000; 10(4):255-70. [DOI:10.1002/1099 1298(200007/08)10:4<255::AID-CASP582>3.0.CO;2-M]

[26] Sorensen G, Emmons K, Hunt MK, Johnston D. Implications of the results of community intervention trials. Annu Rev Public Health. 1998; 19(1):379-416. [DOI:10.1146/annurev.publhealth.19.1.379] [PMID]

[27] Morgan LM. Community participation in health: Perpetual allure, persistent challenge. Health Policy Plan. 2001; 16(3):221-30. [DOI:10.1093/heapol/16.3.221] [PMID]

[28] Costanza R, Fisher B, Ali S, Beer C, Bond L, Boumans R, et al. Quality of life: An approach integrating opportunities, human needs, and subjective well-being. Ecol Econ. 2007; 61(2-3):267-76 [DOI:10.1016/j.ecolecon.2006.02.023] 